IJMS 17 (Special Issue), 101-118 (2010)

\title{
THE GLOBAL CRISIS, TRADE, AND THE MALAYSIAN ECONOMY
}

\author{
SHANKARAN NAMBIAR \\ Malaysian Institute of Economic Research
}

\begin{abstract}
The importance of trade to the Malaysian economy cannot have been more strongly expressed than through the recent global crisis. Malaysia was vulnerable being a small open economy that has an export-dependent manufacturing sector. The very countries that generate the demand for Malaysia's exports were struck by the crisis. As can be expected, Malaysia's exports plummeted. The impacts of the crisis, consequently, caused reduced activity in the manufacturing sector and resulted in a sharp contraction in output. The crisis demands that policy makers take the challenge of strengthening the export sector more seriously.
\end{abstract}

\section{Introduction}

The Malaysian economy has been hit by crises in the past, but the current crisis is quite unlike some of the crises that have inflicted it in recent times. The present crisis presents an extraordinary challenge because the trigger comes from external sources and demands nothing less than a serious reconsideration of the country's growth strategy. The 1997 crisis, for instance, required temporary measures, such as instituting capital controls and more fundamental measures such as the restructuring of the banking and financial system (Ariff, Piei, Azidin, Ong \& Tan, 1998; Ariff \& Yap, 2001; Nambiar, 2003). But the present crisis would require new ways of thinking about how Malaysia could re-position itself since the crisis attacks the very foundations on which the country's growth strategy is based.

The present crisis, if it were to lead to a continued decline in consumer demand from the United States (US), the European Union (EU), and Japan for a considerable length of time (as it seems likely), would mean a softening of export-led growth as we know it in Malaysia. While Malaysia cannot hope to rely entirely on domestic demand to drive the growth of its economy, there is a need to revisit neglected 
aspects of the economy. This implies a repositioning of the economy and along with it national strategies that take a different approach to trade and investment, although it does not mean that export and export-related related activities should be dismissed.

This paper demonstrates the importance of trade channel as a route for transmission of the global crisis, and it suggests that serious efforts should be taken to develop a more resilient export-led growth strategy. The section that follows provides a discussion on the importance of trade to the economy and Malaysia's reliance on demand that is generated by developed economies. The third section analyses the impact of the current crisis on the Malaysian economy. The fourth section suggests possible strategies that could be adopted to make the export-oriented sectors of the economy more resilient. Finally, some concluding remarks are made.

\section{Why Malaysia was Vulnerable to the Current Crisis}

It is easy to see that the current global crisis would impact upon Malaysia via the trade channel. To start with, Malaysia is a very open economy, with total exports and imports totalling RM1,110 billion, a figure that is equivalent to two times the national gross domestic product (GDP). For a country that is as dependent on trade as Malaysia is, it is obvious that if external demand from the country's dominant trade partners were to slow down, its repercussions would be felt throughout the economy. The evidence for the extent of dependence on trade is striking if one were to note the structure of Malaysia's exports.

An examination of the structure of exports clearly indicates the dominant position occupied by manufactured goods, which has been accounting for something like $82 \%$ of total exports (Table 1 ). This is followed in importance by minerals which contributes about $8 \%$ of exports. The share of agricultural commodities accounts for about $7 \%$ of total exports.

Within the category of manufactured goods, electronics, electrical machinery and appliances contributes about $53 \%$ of the share of exports. This category of commodities drives the manufacturing sector. Again, as a component of this broad category, electronic goods are the most dominant. Exports of electronic products can be sub-divided into semiconductors, and electrical equipment and appliances, both of which take a place of roughly equal importance; but the latter claims a slightly larger share of exports. 


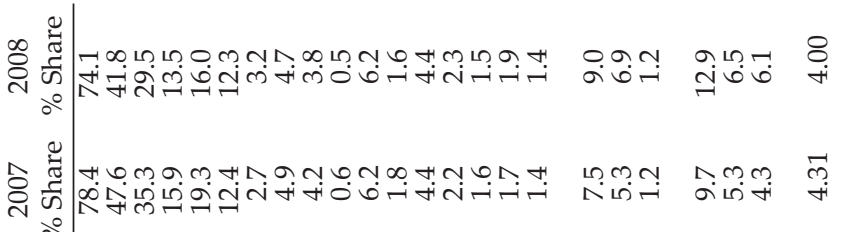

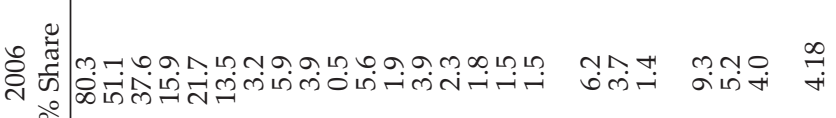

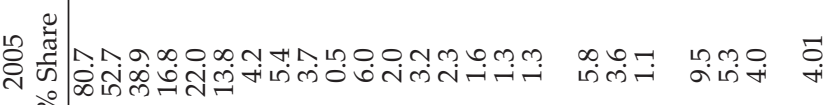

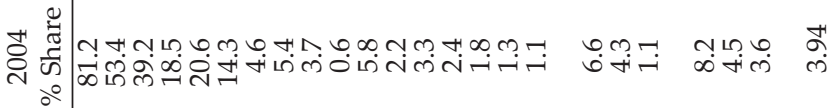

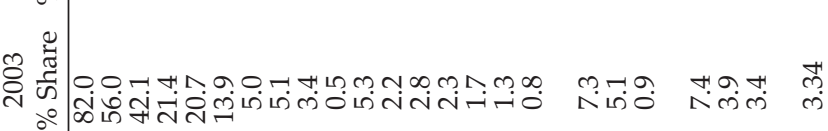
ల్ 2.

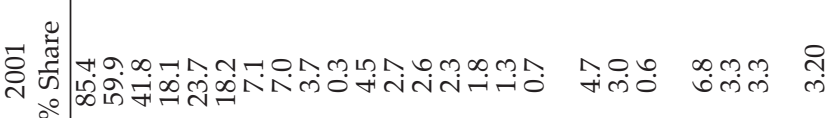
8 :

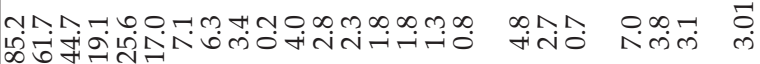
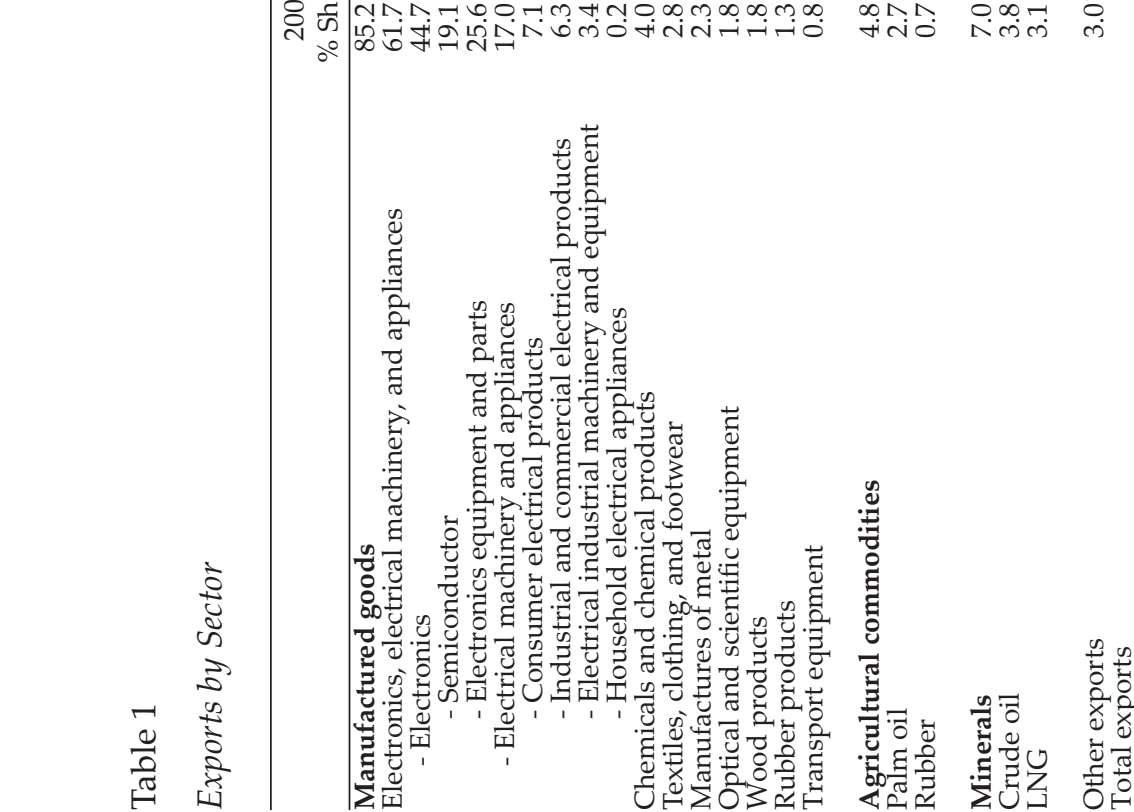

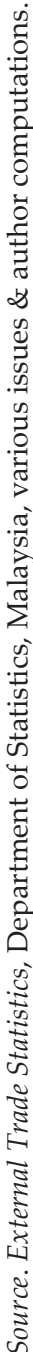


There is no doubt that the export of manufactured goods is particularly vulnerable to drops in external demand. Since the demand for electronic goods largely emanates from developed countries, particularly the US, EU, and Japan, a decline in consumption in these economies is bound to impact negatively on the exports of Malaysian manufactured goods. It is not by accident that the percentage share in total exports has slipped the most from the previous year (2007) as compared to that for 2008, in goods such as semiconductors $(2.4 \%)$ and electronic equipment (3.3\%). The export of electronics, electrical machinery, and appliances fell by $5.8 \%$ in 2008 as against 2007. While manufactured goods accounted for $78.4 \%$ of total exports in 2007 , it contributed $74.1 \%$ in 2008 .

Other items such as chemicals and chemical products; textiles, clothing, and footwear; manufactures of metals; and optical and scientific equipment do not constitute a large share of Malaysia's exports. In 2008, chemicals made up $6.2 \%$ of exports and manufactures of metals contributed $4.4 \%$. Neither of them experienced any change from the previous year. The other items mentioned accounted for less than $2 \%$ in 2008, with the exception of optical and scientific equipment $(2.3 \%)$; but they, too, were not touched by the global crisis. The data strongly suggests that Malaysia's export structure is such that those goods that are exported to developed countries have a degree of importance that outweighs other goods. Not only must we note that the country's growth is largely dependent on its trade, but also that the export structure is heavily balanced in favour of manufactured goods. Furthermore, Malaysia's export-driven manufacturing sector depends on goods derived from the electronics and electrical sector.

The vulnerability of Malaysian exports is reconfirmed from an examination of trends in exports by Malaysia to its major trading - partners. The US used to be the largest single destination for exports in the mid-1990s (Figure 1). However, it seems to have lost its favoured position, as other countries have come to take a place of, roughly, equal standing. In 1995, about $21 \%$ of exports were directed to the US, with a gentle decrease to about $18 \%$ in more recent years.

The EU stood next in importance as a destination for Malaysia's exports in 1995, claiming $14 \%$ of exports. The share of exports heading for the EU has hovered around 12.5\% in recent years. Japan, to which about $13 \%$ of Malaysia's exports went, now demands about $9 \%$. The biggest decline has been noted in the case of Singapore. In the late 1990 s, about $20 \%$ of exports went to the city-state. Since 2006, the figure has come down to about $15 \%$. China, on the other hand, has been assuming a place of greater significance as a destination for 
Malaysia's exports. About 3\% of exports went to that country in the late 1990s, but in the last two years this figure has almost tripled. The five most important economies to which Malaysia's exports go to are the US, Singapore, the EU, Japan, and China, more or less in that order of importance until 2007. In 2008, Singapore assumed a position of greater importance than the US.

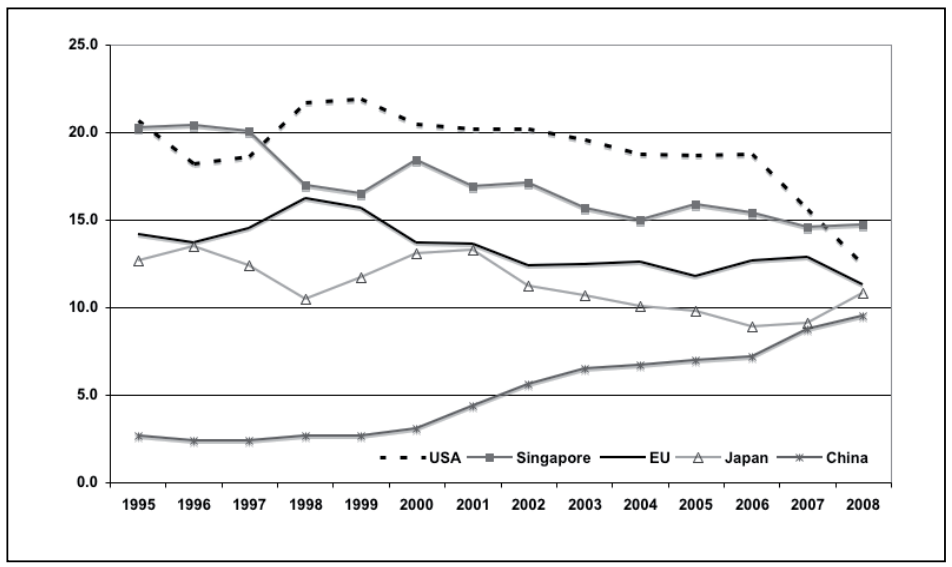

Source. Department of statistics.

Figure 1. Malaysia: Exports to major partners.

There is some convergence in terms of import sources. In the mid and late 1990s, Japan was the largest import source, followed by the EU and Singapore (Figure 2). While 27\% of exports were directed to Japan in 1995, the figure dropped to $13 \%$ in 2007 , and a notch lower in $2008(12.5 \%)$. The US accounted for about $16 \%$ of total imports between 1995 and 1997. In the years 2007 and 2008, only $10 \%$ of imports were from this country. About $11 \%$ of imports are from the EU. China, however, was a source of only $2.2 \%$ of imports in 1995, but this picture has been improving. In 2005 the same figure shot up to $10 \%$ and edged up to $12.9 \%$ in 2007.

There is a strong relationship in Malaysia between exports and imports in that the goods produced for export have strong import content. Also, the same countries serve as destinations for export and sources of import. Again, these are the countries that have suffered severely from the impact of the current global crisis. Given the fact that Malaysia's growth relies to a high degree on export-oriented 
manufacturing it should not be surprising that the impact of the crisis is felt on the Malaysian economy. This is a matter that will be discussed in the next section.

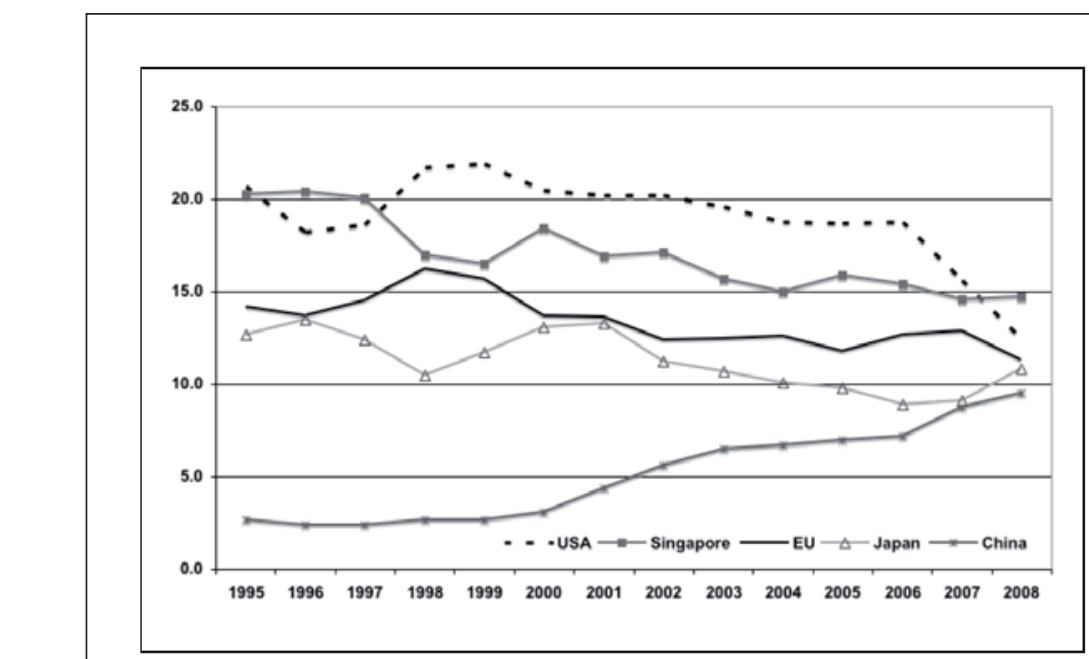

Source. Department of statistics.

Figure 2. Import sources.

\section{Impact of the Crisis on the Malaysian Economy}

Two indicators that were among the economic indicators to feel the impact of the current crisis were exports and the industrial production index. Export figures, which were doing well in the first three quarters of 2008, took a downturn toward the end of that year (Figure 3). In January 2008, exports increased by $10.4 \%$ (year-on-year), and more or less doubled to $20.9 \%$ in April 2008. However, in October 2008 a negative figure was reported $(-2.6 \%)$, only to decline more deeply as the months progressed. In December 2008 a decline was registered $(-14.9 \%)$, which worsened in January $2009(-27.8 \%)$.

Imports, which tend to follow export trends rather closely in Malaysia, reported a similar pattern. Imports increased by about $11 \%$ (year-on-year) in February 2008 and exceeded 10\% in the months of June and July 2008 (12.5\% and $15.0 \%$, respectively). Again, the change in imports dived into negative territory from October 2008, falling from $-5.3 \%$ in that month to $-23.1 \%$ in December 2008, and further dropping to $-32.0 \%$ in January 2009. It is understandable that 
imports should fall along with decreases in exports because imports of intermediate goods are required to meet the production of exports. With the strong demand for exports that emanates from Malaysia's major trading partners (US, Japan, and the EU) having fallen, it was only to be expected that exports from Malaysia would also fall.

Since most of the manufacturing sector is driven by the growth of exports, it stands to follow that the industrial production index (IPI) would reflect the damp export conditions imposed by the global environment. Accordingly, the IPI has been sinking since September $2008(-1.7 \%$, year-on-year), deepening toward the end of 2008, particularly in December, and right into January 2009 $(-15.9 \%$ and $-20.2 \%$, respectively) (Figure 3$)$. These results are not surprising in view of a) Malaysia's heavy dependence on the E\&E (electrical and electronics) sector and b) the fact that Malaysia's major trading partners were badly affected by the global crisis. Claims that Malaysia has decoupled from the US cannot be defended against these outcomes. The other argument that is made is that Malaysia is shifting its trade towards ASEAN. While there is evidence that trade with Singapore and Thailand has been increasing, this phenomenon must be juxtaposed against the nature of production networks. Units in other parts of ASEAN are a part of the production processes where the final products are ultimately exported to countries such as the EU and the US.

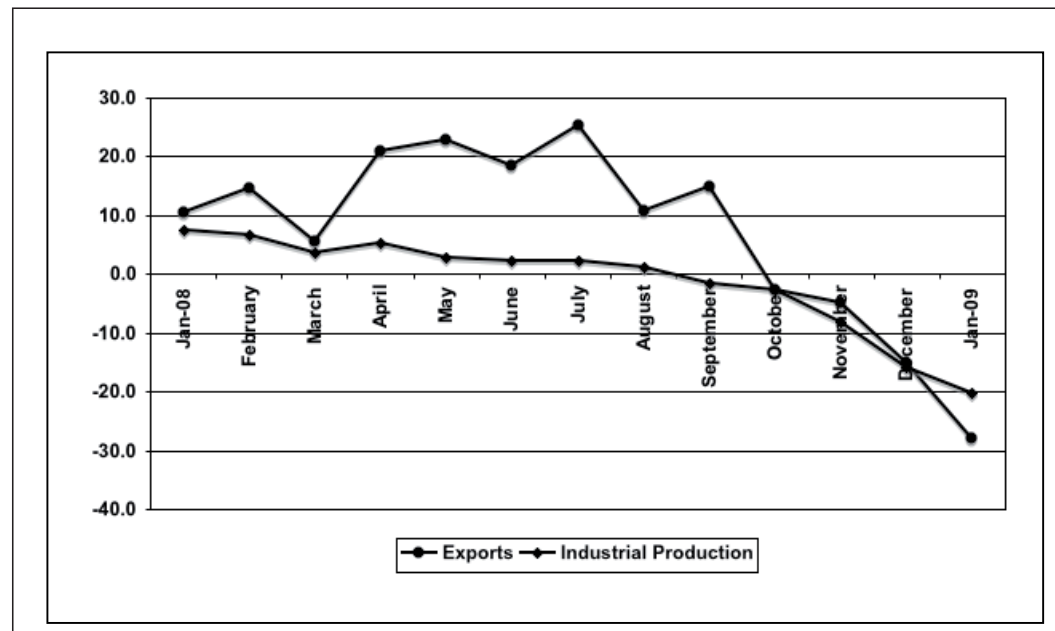

Source. Department of statistics.

Figure 3. Exports/industrial production trends. 
The effects of the crisis began to show through in the GDP numbers by the third quarter of 2008. In no sector was this clearer than the manufacturing sector (Figure 4). The manufacturing sector had a 5.6\% increase (year-on-year) in the second quarter of 2008. In the following quarter it was positive, but closer to $2 \%$ (1.8\%, to be exact), and it was negative $(-8.8 \%)$ by the fourth quarter of 2008 . The construction sector also showed negative growth in the fourth quarter of 2008. In fact, real GDP slid down to a 0.1 per cent growth in the last quarter of 2008.

Viewed in terms of real GDP by demand expenditure, the most striking decreases in the fourth quarter of 2008 were observed in gross investment $(-10.2 \%)$, exports $(-13.4 \%)$, and imports $(-10.1 \%)$ (Figure 5). Private consumption also fell, but remained at a respectable rate of $5.3 \%$. By way of comparison, in the first quarter of 2008 private consumption had increased by $11.7 \%$. Similarly, in the same quarter gross investment increased by six per cent, with exports and imports showing increases too (at $6 \%$ and 3.4\%, respectively). The net effect of all the decreases in the various components of real GDP was a decline in real GDP growth to $0.1 \%$ for the last quarter of 2008, as against about $7 \%$ in the first half of the same year.

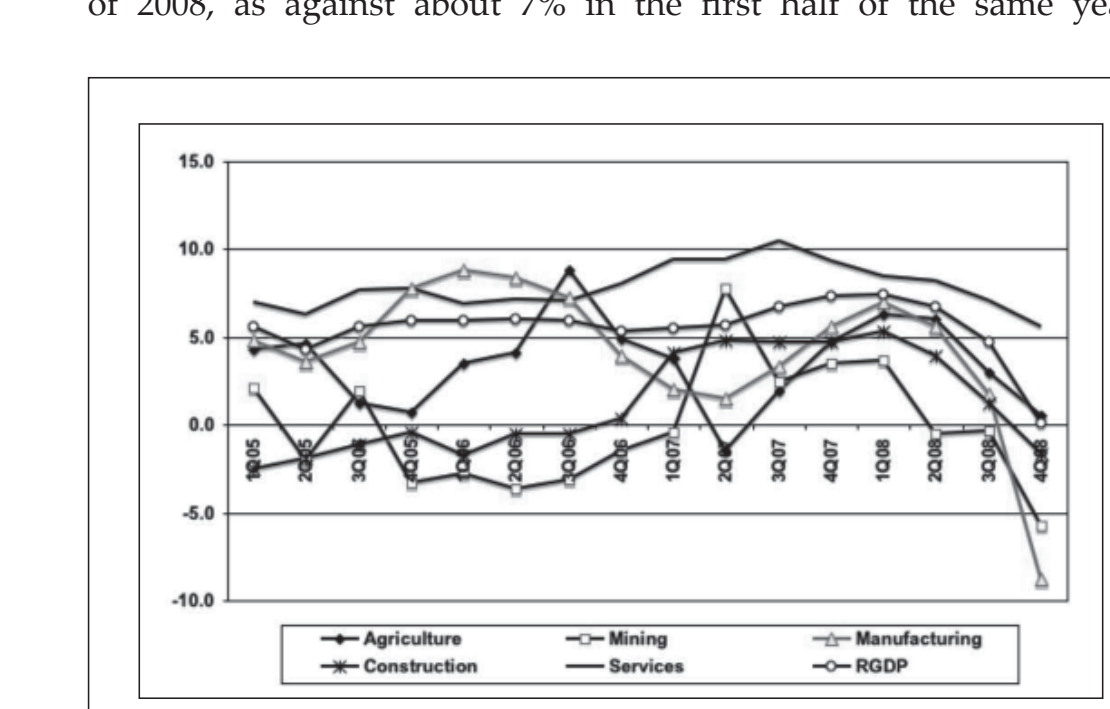

Source. Department of statistics.

Figure 4 . GDP by sectors (\% change).

The capital outflows from Malaysia increased with the onset of the crisis. Firstly, reverse investments that were high in the second half of 2007 (about RM10 billion), slowed down in the fourth quarter of 
2008 (RM6.5 billion). The outflows of portfolio funds from Malaysian markets were a remarkable signpost of the reality of the global crisis. There was a surge of portfolio flows into the country in the first quarter of 2008 (RM21.0 billion). But starting from the second quarter the outflows have been massive: in the second quarter portfolio, outflows amounted to RM24.0 billion and in the third quarter they hit RM56.1 billion, flowing out again in huge amounts in the fourth quarter of 2008 (RM33.2 billion).

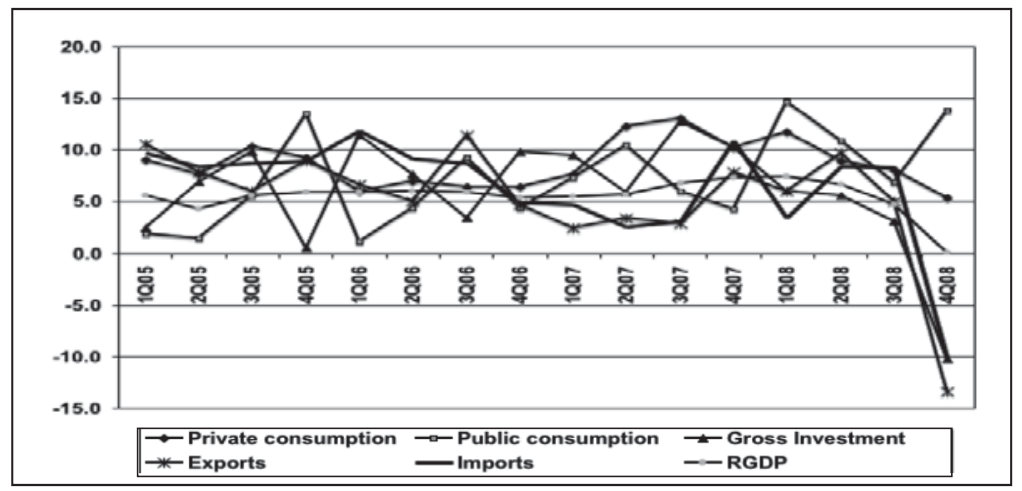

Source. Department of statistics.

Figure 5. Real GDP by demand expenditure (\% change).

Foreign direct investments (FDI) did not in any way compensate for portfolio outflows during the same period. In fact, FDIs have been hovering at around RM5 billion every quarter in recent years (20062008). There have been occasional spurts of FDI inflows into Malaysia. In particular there was one in the second quarter of 2007 and another one in the second quarter of 2008. The big increases in FDI that took place in 2Q 2007 amounted to RM11.5 billion while that in 2Q 2008 touched RM17.3 billion. The earlier one was because of foreign investors (from Japan, the US, Germany, and Singapore) making investments in E\&E activities, while the latter was because of a huge joint venture enterprise initiated by an Australian company relating to aluminium processing. There is no doubt that with the crisis, and with Malaysia's traditional FDI sources being hit, FDI inflows are affected. This was seen distinctly in the third quarter of 2008 when FDI worth RM0.9 billion was all that flowed into the country, but it recovered to RM5.0 billion the following quarter (Figure 6). The full 
effects of the crisis on FDI are perhaps yet to be seen, since decisions to invest in foreign countries will be decided upon by multinational corporations (MNCs) and realised a few years after the present time period (i.e. after the second half of 2008).

The crisis has also prompted a rundown on the foreign reserves that Malaysia has been holding. The economy held foreign reserves valued at US $\$ 314$ billion in 2006. Reserves have been increasing in 2007 (US\$386.4) and a further increase was noted in 2008 (US\$447.2). Malaysia's reserves have, indeed, been high in the years subsequent to the 1997 crisis, but the present crisis has had its toll on reserves. Quarterly figures depict the reality of the crisis. In the second quarter of 2008, reserves amounted to US $\$ 125.8$ billion, but fell to a limited extent in the following quarter of the same year (US\$109.7 billion). However, in the last quarter of 2008 the fall was even sharper, reaching US $\$ 91.5$ billion, implying a dip of US $\$ 18.2$ billion of that held in the preceding quarter.

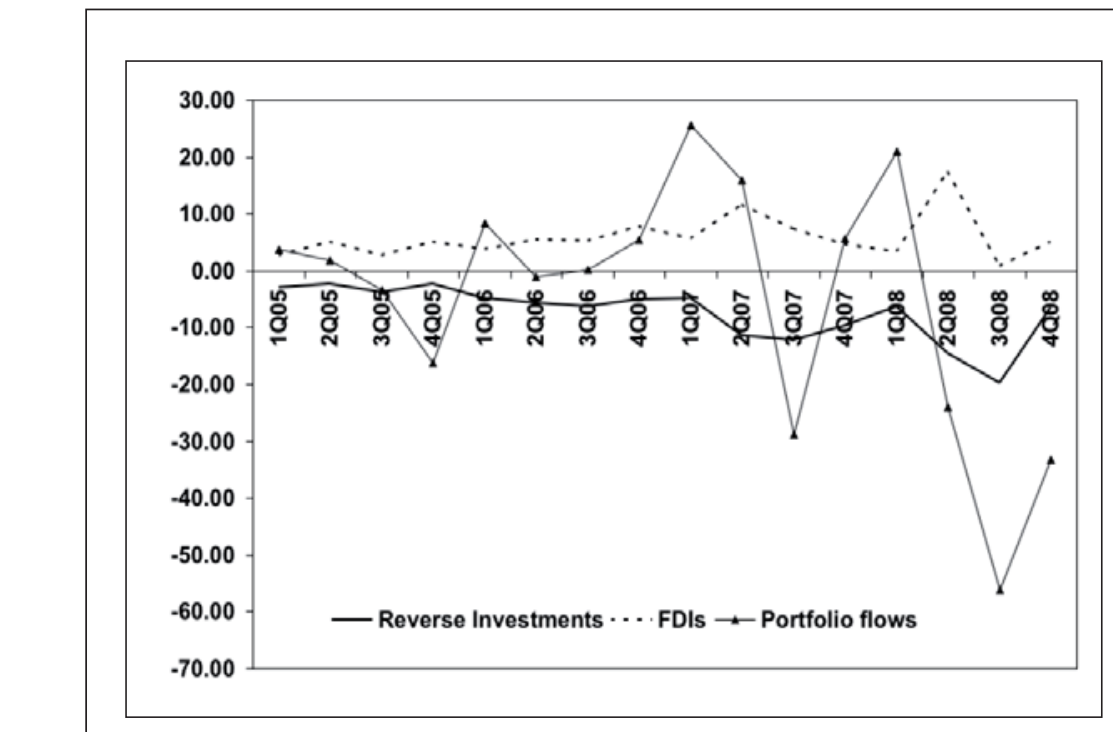

Source. Department of statistics.

Figure 6. Capital flows (RM billion).

The declines in FDI, foreign reserves, and portfolio funds have been well-cushioned by the relatively stable current account balance. There is no doubt that in the fourth quarter of 2008, the current account 
balance did drop to RM29.8 billion against the figure in the previous quarter (RM38.7 billion). But more striking is the overall balance which had been dropping drastically since the third quarter of 2008, falling from -RM31.5 billion (third quarter of 2008) to-RM61.9 million in the last quarter of 2008.

The brunt of the crisis' impact on the Malaysian economy is felt most strongly on certain sectors of the economy. One such sector is the manufacturing sector, as was discussed earlier. Another sector that is affected is the construction industry. This is seen from some of the indicators on the construction industry. The number of new sales permits has been falling from July 2008, but the figures highlighted the pessimism of the industry most distinctly from August 2008. The number of new sales permits, which earlier in the year reached 87, fell to 58 in August and came down to 41 in December 2008. The number of housing approvals had also been on the downtrend. The change in the production of construction-related products showed the bleak outlook of the industry. In September 2008 there was a 6.8\% increase (year-on-year) in this index; it fell in October (1.9\%); but was most distressing in November 2008 (-5.1\%).

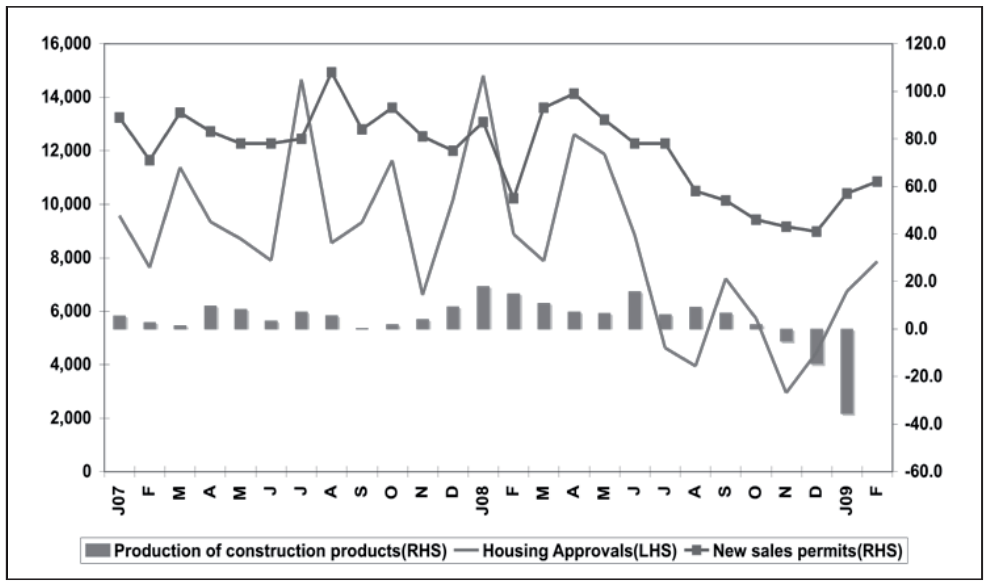

Source. Bank Negara Malaysia.

Figure 7. Property sector indicators.

The more prominent sectors in the economy were already beginning to suffer from the impact of the crisis. With the negative reactions that were felt by the E\&E sector, construction, and property development, 
it is to be expected that the local markets will be beset with gloom. Naturally, this has its impact on the financial sector. Given the uncertainty that envelopes the economy, and with declining consumer sentiments, there is nothing surprising about the attitude of caution that had struck the markets, particularly credit markets. This makes it easy to see why loans approved have been slipping down (Figure 7). Especially since September 2008, the growth in loans approved had been in the negative region $(-2.9 \%)$. Loans approved have since been decreasing, markedly in the months of October $(-14.4 \%)$, November $(-44.0 \%)$, and even in January $2009(-35.6 \%)$. The caution exercised in the banking sector was indicated by the growth in loans disbursed. This, too, had declined in the months of October (8.2\%), November $(7.6 \%)$, December $(0.6 \%)$, and landed into negative territory in January $2009(-10.0 \%)$.

The overall atmosphere of negativity has led to loss of employment. The manufacturing sector, as one can very well imagine, has suffered the most from the crisis in terms of retrenchments. This has been marked in the second half of 2008; in the third quarter of 2008, about 10,000 workers were retrenched; and about 5,000 lost their jobs in the last quarter of that year (Figure 8). Retrenchments were also high in the services sector, again, in the third and fourth quarters of 2008. Except in the agriculture sector, retrenchments have been high, and a total of about 20,000 workers were retrenched in the second half of 2008 according to published statistics.

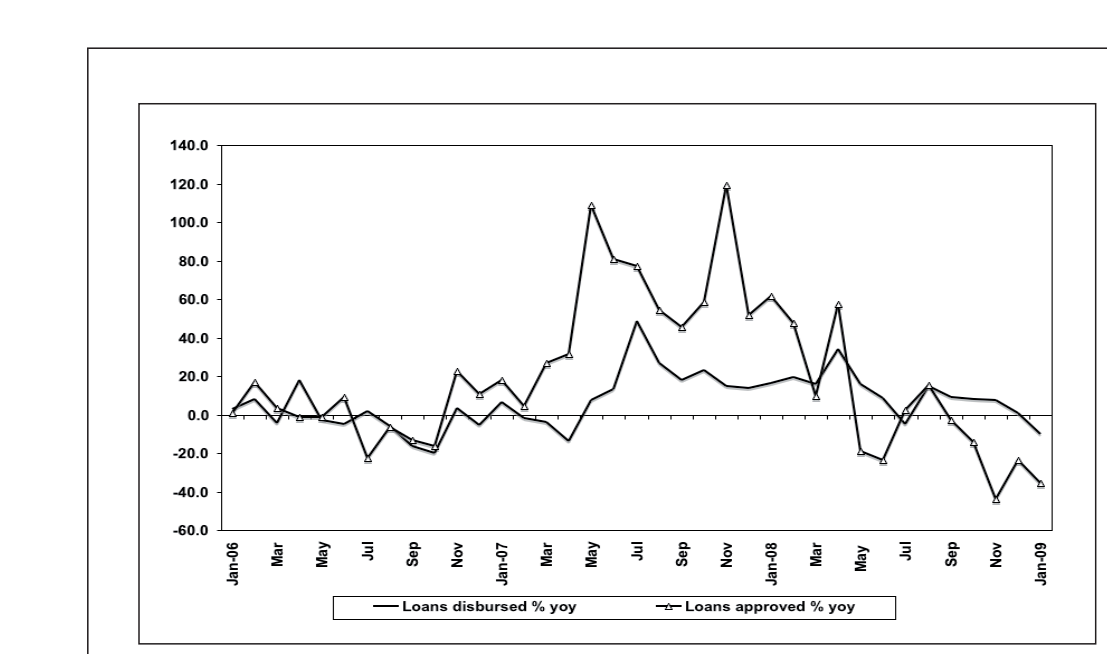

Source. Bank Negara Malaysia.

Figure 8. Loans approved and disbursed. 


\section{Strategising for Growth}

What has happened in the months that have come to pass, challenges two assumptions that policy makers have not deeply questioned thus far: 1) Malaysia's comparative advantage in its E\&E exports, and 2) the prevailing predominance of the US, Europe, and Japan as Malaysia's sustained destinations for its exports. It is not clear when the developed economies which form the bulk of Malaysia's export destinations will recover from the present crisis, how prolonged it will be, and whether the pattern of global recovery will be " $\mathrm{V}$ ", " $\mathrm{U}$ ", or "L-shaped."

The uncertainties that lie ahead place additional pressure on the manufacturing sector in Malaysia since the initial challenge that the sector had to face, and has not yet come to terms with, is the competition that has been coming from developments in China and Vietnam. The fact that Malaysia ceases to have the comparative advantage that it used to have on the basis of its stock of cheap, compliant, and welleducated labour has led to concerns about the inflow of FDI. There is more competition for FDI and Malaysia cannot compete on the terms that it could, say, 10 years ago, since it neither has the unskilled labour advantage that it used to have, nor does it have an abundant supply of skilled, knowledge-intensive labour. To this must be added the problems caused by the present crisis, which exacerbates the problem, particularly if the demand from the developed economies that Malaysia has traditionally depended upon does not recover to the pre-crisis levels. Should that happen, Malaysia's growth rates will take a beating, and with that other macroeconomic variables will be affected, particularly employment, not to mention the levels of wellbeing that the economy is used to.

In view of the current global crisis, and especially if it is going to be prolonged, Malaysia will have to readjust its growth strategies. The support for its export-oriented policy comes from other elements of the policy landscape and involves:

1. a suitable industrial policy,

2. export promotion institutions and strategies, and

3. fiscal incentives.

While these policy elements are domestic in nature, they must be coupled with a reorientation in those aspects that are more outward-looking. The latter implies that a re-examination is called 
for with regard to: a) export products (goods and services), b) export destinations, c) policies with regard to initiatives to attract FDI, and d) improving competitiveness.

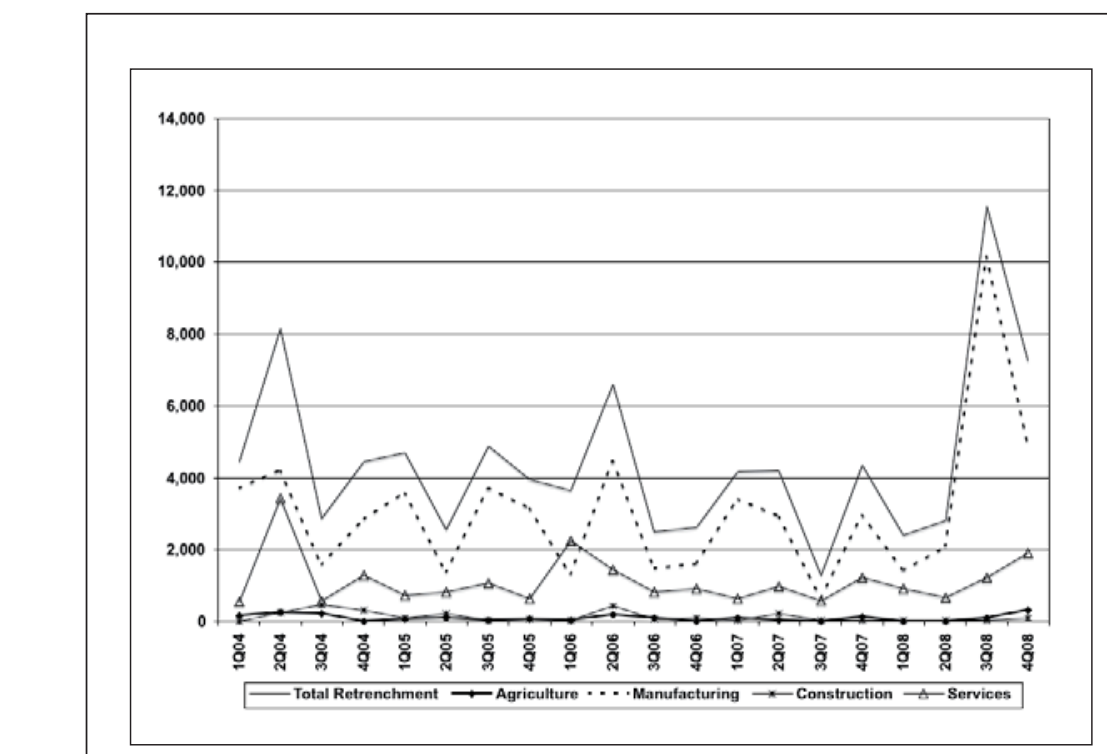

Source. Ministry of human resources.

Figure 9. Retrenchments.

There is a strong call for Malaysia to adopt policies that are directed toward rebalancing growth (Nambiar, 2009). This follows from the argument that under the prevailing circumstances it would be best to take a more inward-looking route, concentrating on the development of domestic fundamentals and markets (James, Park, Jha, Jongwanich, Terada-Hagiwara \& Sumulong, 2008; ADB, 2009). While there is some merit to these claims, there are serious limitations that have to be contended with. Some of the restrictions that arise from this line of thinking relate to the demographic profile of the economy, which has a population of about 27 million, making it impossible to depend entirely on domestic demand to drive industrial development.

No less important is the fact that industrial policy in the last 20 years has been centred around increasing export growth. It is through the channel of export-led economic growth that the government has tackled employment generation and poverty eradication (Nambiar, 2005; UNDP, 2006). The government's five-year plans and industrial

114 IJMS 17 (Special Issue), 101-118 (2010) 
policy have been largely premised on this phenomenon. The lack of scope for depending upon a substantial domestic market, and the long track record of reliance on export-led growth, together present a model for growth that cannot be undone in the next few months, perhaps not even in the next few years. Not only has this model served well, but the scope for a domestically oriented model does not have adequate support to build upon. Re-orientation, in this context, implies engineering new initiatives, and further strengthen the existing export-led strategy.

The process of creating export-oriented resilience would require a re-consideration of the elements of export-led growth that have been employed in the past. This would entail, on the side of enhancing exports, a consideration of new products and new destinations. A crucial consideration would be to improve competitiveness. There are two dimensions to this: a) product competitiveness and b) institutional support for competitiveness. The latter would involve commitment to competition law and policy, so that the principles of national treatment and most favoured nation are observed as guiding tenets. The question of establishing an open policy with regard to government procurement would also demonstrate Malaysia's willingness to provide MNCs with a level field to participate in this market. Introducing competition policy and adopting a more transparent and accessible approach to government procurement would together constitute two crucial steps in creating a favourable institutional environment.

In terms of improving its product competitiveness, Malaysia has to pursue policies that encourage technological upgrading, strengthen public-private participation in export-promotion, and build publicprivate networks to encourage research and development (R\&D) that has commercial value. There are two issues that are involved in fostering product competitiveness. The first relates to more knowledge-based production methods that would push the products up the value chain. This requires technological upgrading and more knowledge-intensive human capital. The process of technological upgrading would be facilitated through the presence of wellfunctioning R\&D networks. The second issue relates to marketing, creating a brand name, and gaining recognition in international markets. This aspect demands deeper public-private cooperation for export-promotion.

With regard to export strategies, the government needs to explore new trade destinations. The Malaysia-Pakistan Closer Economic Partnership Agreement is one instance of a move toward attempting to 
develop a diversification in Malaysia's trade partners. However, more has to be done in a similar mode and potential economies with greater impact potential have to be selected. Of particular interest would be emerging economies with burgeoning middle-class consumers. As far as export items are concerned, a more concerted effort must be put into exploring new industries that could be encouraged for their potential to contribute to export performance. Even a cursory examination of Second and Third Industrial Master Plan documents and the Eighth and Ninth Malaysia Plans attest to the fact that the Malaysian government has been trying to encourage the growth of new manufacturing industries that will have export potential. Obviously, the intention has long been to obtain a higher degree of diversification than now prevails, with the huge reliance on the export of commodities coming from the electrical and electronics sector. Despite the long-standing objective of developing new industries, the data (see Table 1) showed no evidence of increased exports in areas other than the E\&E sector or in palm oil. This objective now needs to be pursued with greater seriousness.

Clearly, there are policy measures that the Malaysian economy should be doing and has been cognisant of well before the crisis. However, the government needs to ensure that its export-oriented growth strategies will work post-crisis by improving Malaysia's competitiveness and strengthening its regional ties. The Malaysian economy should be more deeply integrated within ASEAN, looking beyond its trade relations with Singapore. It should also seek to take advantage of opportunities that come within the ASEAN+10 framework.

Since the crisis, the government has introduced two stimulus packages, one amounting to RM7 billion and the other valued at RM60 billion. These were announced on 4 November 2008 and 10 March 2009, respectively. Most of the allocations under the first package were directed at improving housing and infrastructure. The second package took a more comprehensive approach, targeting: a) unemployment, b) vulnerable sections of society, c) support for the private sector, and d) capacity-building for the future. Of particular interest are allocations to Khazanah Nasional Berhad, a government investment arm for investment in telecommunications and technology. Funds have also been set aside to boost private investment activities through private finance initiatives and public-private partnerships. The development of new technologies, particularly biotechnology, had been earmarked, as has been human resource development. The importance of attracting FDI has not been overlooked in the stimulus 
packages. The second package, in particular, directed funds toward the Iskandar Development Project, a project that seeks to develop a corridor in the southern part of Peninsular Malaysia. The fact that that these areas have received attention indicates that the government realises that the export-led growth strategy must be refined and made more resilient. This has to be done in such a fashion, as we have indicated, to bolster Malaysia's state of competitiveness.

\section{Conclusion}

Malaysia's response to the economic and financial crisis of 1997 was a set of unorthodox policy measures, highlighted by the use of capital controls. This was complemented by institutional measures, some of which were temporary, as was the establishment of organisations to restructure debt, while others were more of a long-term nature. Among those in the latter category, were actions taken to strengthen the banking sector through the merger of banks and initiatives for the phased liberalisation of the financial sector.

At the centre of Malaysia's development plans stands its exportoriented growth strategy. Aside from promoting exports, this has implied encouraging and providing incentives for export-oriented manufacturing and the promotion of exports. Closely related are efforts to attract FDIs and support the location of MNCs in Malaysia. In view of the nature of the current crisis and economies involved, there is an urgent need to improve upon these policies. In fact, the crisis calls for strategies that will spell a structural change in the economy. These changes can only come from a transformation in Malaysia's key assets, that is, a highly skilled labour force, technological upgrading, an environment that is attractive for the inflow of FDI, and the development of new industries with export potential. Alongside these attempts, the institutional structure has to be improved to inspire confidence in MNCs to invest in Malaysia. Recognising the vulnerability of the export-driven sectors, care must be taken to adopt a policy of diversification of exports, manufacturing industries, and the type of MNCs being located in the country.

\section{Acknowledgements}

I gratefully acknowledge the editor's useful comments. However, all shortcomings are entirely mine. 


\section{References}

Ariff, M., Piei, M. H., Azidin, W., Ong, G. E., \& Tan., E. L. (1998). Currency turmoil and the Malaysian economy: Genesis, prognosis, and response. Kuala Lumpur: Malaysian Institute of Economic Research.

Ariff, M., \& Yap., M. M. (2001). Financial crisis in Malaysia. In T. $\mathrm{Yu} \&$ D. Xu (Eds.), From crisis to recovery: East Asia rising again? Singapore: World Scientific.

Asian Development Bank (ADB). (2009). Asian development outlook 2009: Rebalancing Asia's growth. Manila: Asian Development Bank.

James, W., Park, D., Jha, S., Jongwanich, J., Terada-Hagiwara, A., \& Sumulong, L. (2008). The US financial crisis, global turmoil, and developing Asia: Is the era of high growth at an end? ADB Economics Working Paper Series No.139. Manila: Asian Development Bank.

(1) Nambiar, S. (2009). Malaysia and the global crisis: Impact, response and rebalancing strategies. Paper presented at the ADBI Conference, 22-23 April, Tokyo.

Nambiar, S. (2005). Social capital and poverty eradication: Some Issues from the Malaysian experience. In S. Nambiar (Eds), Development Paper No. 26: Income generation and poverty reduction: Experiences of selected Asian countries. Bangkok: UNESCAP.

Nambiar, S. (2003). Malaysia's response to the financial crisis: Reconsidering the viability of unorthodox policy. Asia-Pacific Development Journal, 10(1), 1-23.

United Nations Development Programme (UNDP). (2006). Malaysia: International trade, growth, poverty, and human development. Kuala Lumpur: UNDP. 